\title{
モンゴル草原における広域観測領域を代表する最小面積に関する研究
}

\section{The Minimum Representative Area for Large Observation Site in Mongolian Grassland}

 \\ Yoshiaki HONDA, Koji KAJIWARA, Hirokazu YAMAMOTO, Chiharu OKANO, \\ Shaobo HUANG and Masayuki MATSUOKA
}

\begin{abstract}
To verify the reliability of the algorithm for speculating physical variable from $1 \mathrm{~km}$ satellite data, it is necessary to use the ground observational data to calculate physical value in a wide survey unit $(1 \mathrm{~km} \times 1 \mathrm{~km})$. Since it is difficult to conduct the ground observation within whole wide survey unit in short time, the minimal survey area which can represent a wide survey unit has to be determined. The research is armed to find the minimal representing area of a wide survey unit through the car survey and radio-controlled helicopter survey.

Flat and homogeneous grassy plain in Mongolia is chosen as survey land. In case of car survey, 100 observational points are measured. VCR (Vegetation Coverage Ratio) values are calculated from spectrum information and used to compute the moving-averages of VCR. With the increasing of point number, the standard variation of moving -averages becomes smaller and smaller. When the variation approximately disappears after $\mathrm{N}$ points, the moving -average of VCR is considered as the observational value which can represent the value in wide survey unit. The total area size of $\mathrm{N}$ points at this time will be the minimal representing area of the wide survey unit.

Moreover, the result from the car survey may be obtained occasionally from ground surface in same situation. To confirm the result, additional observational data are taken from higher sky using radio-controlled helicopter. Each observational point has about minimal representation area. The standard variation of moving-averages in this case is very small. So it can be said that the method used in the research is a good way to calculate the minimal representing area of a wide survey unit.
\end{abstract}

\section{1.はじめに}

NASA が提唱した Earth System Science(1984)に は最初の 10 年で地球の様々な情報を集め, 次の 10 年で モデル化を行い, 最後の10年で地球上で生じる様々な 事象の予測手法を確立することを目指すとされてい た。

1970年代から開始された衛星による地球観測は, Landsat, SPOT, MOS 等の多くの技術試験衛星の運 用と技術の蓄積・進展を経て, 1996年夏の地球観測衛 星 $\mathrm{ADEOS}$ で初めて本格的な地球環境の把握が始

*千葉大学環境リモートセンシング研究センター Center for Environmental Remote Sensing, Chiba University 千葉市稲毛区弥生町1-33

「写真測量とリモートセンシング」VOL. 36, NO. 5, 1997
まったと考えると, Earth System Science で言われて いる最初の 10 年がやっと始まったと言える。

初期の衛星による地球の観測は，地困を作るような 利用のされかたであった。今日では, 地球の様々な事 象を記述するための物理量を時系列で得ることを目的 としている。衛星による地球観測は形状や大きさ，ま た対象の定性的な把握から, 事象のモデル化や予測を 目的とした定量的な計測へと移り変わろうとしてい る。このような衛星地球観測の流れの中で陸上の植生 モニタリングのあり方も移り変わる必要がある。

\section{2. 問題の所在}

衛星観測で得られた情報から物理量を求めること は，地球の物質循環を把握する上で不可欠である。物 理量の把握には, 物理量推定アルゴリズムが必要であ 
る。この推定アルゴリズムがどの程度信頼できるか検 証が必要である。

この検証は衛星観測と同期して, 地表面や海表面で 対象としている物理量を実際に観測して衛星デー夕に よる推定值と比較することで行われる。すなわち, 実 測值が得られないと推定アルゴリズムの正しさすら分 からない。

しかし, 地上解像度 $1 \mathrm{~km}$ (例之ば過去からの NOAA AVHRR データ, 現在の ADEOS OCTS デー 夕, 将来的には ADEOS-II GLI, EOS-AM MODIS データ）に見合った実測值をくまなく短時間で収集す ることは不可能である。このことは, 対象が大気や海 洋のように空間的な一様性が高いものでは特に問題に はならない。しかしながら, 対象が地表面のように一 様性が低い場合は大きな問題となる。たと之一様性が 高いと考えられる観測領域をみつけたとしても，本当 に一様であるかどうかの確認が必要である。また，一 様であると認められるのが，いかなる条件であるかを 明らかにする必要がある。たと之ば，植被がまばらな 草原を対象と考えた場合，ミクロに草原を見ると一株 ごとに草本があるところとないところがあり，一様と は言之ない。つまり, どの程度の範讲を1 ユニットと すると一様であるかという最小単位を明らかにする必 要がある。

\section{3. 研究の目的}

本研究では, 平坦で均質な草本植生が広がるモンゴ ル草原において, 広域観測領域 $(1 \mathrm{~km} \times 1 \mathrm{~km})$ の草 本植生の分布が代表できる一様な最小面積を求めるこ とを目的とする。

\section{4. 観測手法と結果}

一様として観測領域を代表する最小面積を求めるた めに 4.1 車両を用いた方法と 4.2 ラジコンへリを用いた 方法による観測を行った。観測対象地域は四 1 に示す ような一様で平坦なモンゴル草原である。測定日時は 各々1996年 8 月14日と1996年 8 月15日に実施した。こ のときの測定条件を表 1 に示す。

車両を用いた方法, ラジコンへリを用いた方法とも に分光情報と CCD カメラによる画像情報を同時に取 得をすることが可能である。測定簓所は同じであるが,

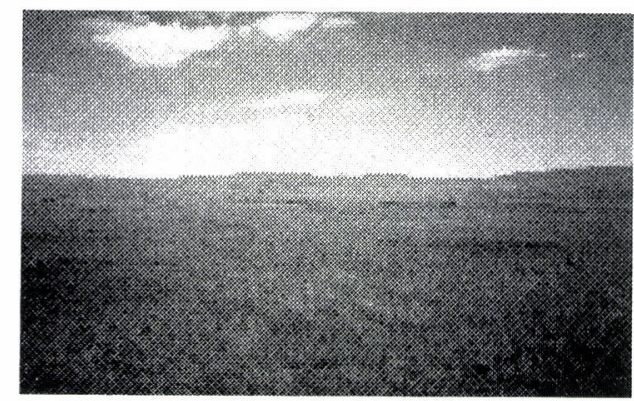

図 1 測定対象地域

表 1 本研究で使用したデータの測定条件

\begin{tabular}{|c|c|c|}
\hline 取 得 日 時 & $\begin{array}{l}\text { 1996年 } \\
8 \text { 月14日 }\end{array}$ & $\begin{array}{c}\text { 1996年 } \\
8 \text { 月15日 }\end{array}$ \\
\hline 取 得 時 間 & $\begin{array}{l}\text { 15時44分 } \\
\sim 17 \text { 時30分 }\end{array}$ & $\begin{array}{l}12 \text { 時05分 } \\
\sim 12 \text { 時10分 }\end{array}$ \\
\hline 積 算 回 数 & 10 & 10 \\
\hline 積 分 時 間 & $0.08 \mathrm{sec}$ & $0.16 \mathrm{sec}$ \\
\hline チャンネル数 & $1024 \mathrm{ch}$ & $512 \mathrm{ch}$ \\
\hline 波長分解能 & $0.68 \mathrm{~nm} / \mathrm{ch}$ & $1.37 \mathrm{~nm} / \mathrm{ch}$ \\
\hline 観 測 角 & Nadir & Nadir \\
\hline 視 野 角 & 約 $22^{\circ}$ & 約 $22^{\circ}$ \\
\hline 度 & $2 \mathrm{~m} 16 \mathrm{~cm}$ & 約 $55 \mathrm{~m}$ \\
\hline データ 数 & 100 点 & 30 点 \\
\hline
\end{tabular}

表 1 に示すように各々の測定日時が異なり, 同じ対象 物でも土袞状態（土壌水分含有量など）による影響で 分光情報が変化する可能性が考えられる。そこで本研 究では直接分光情報を用いて比較することを避け, 両 手法から各々取得できる植生被覆率に基づいて最小面 積の比較を行った。

\section{1 車両を用いた方法}

この方法は眓 2 のように車両の屋根からアームを出 し, その先端にスペクトルメータ, GPSレシーバー, CCD カメラ, GPS カメラ(コニカ製)を装着してあり, 車两を移動させて，迅速に地表面を観測できるもので ある1)。GPSカメラは写真の上部に日時・時間・緯度・ 経度などの情報を写込むことができる。

また CCD カメラ, GPS カメラは分光計の視野と予 め一致させているので, 分光情報と画像情報の照合が 容易である。この観測では 1 点あたり約 1 分間の観測 時間で, $1 \mathrm{~km} \times 2.5 \mathrm{~km}$ の中を困 3 のように100点の観 


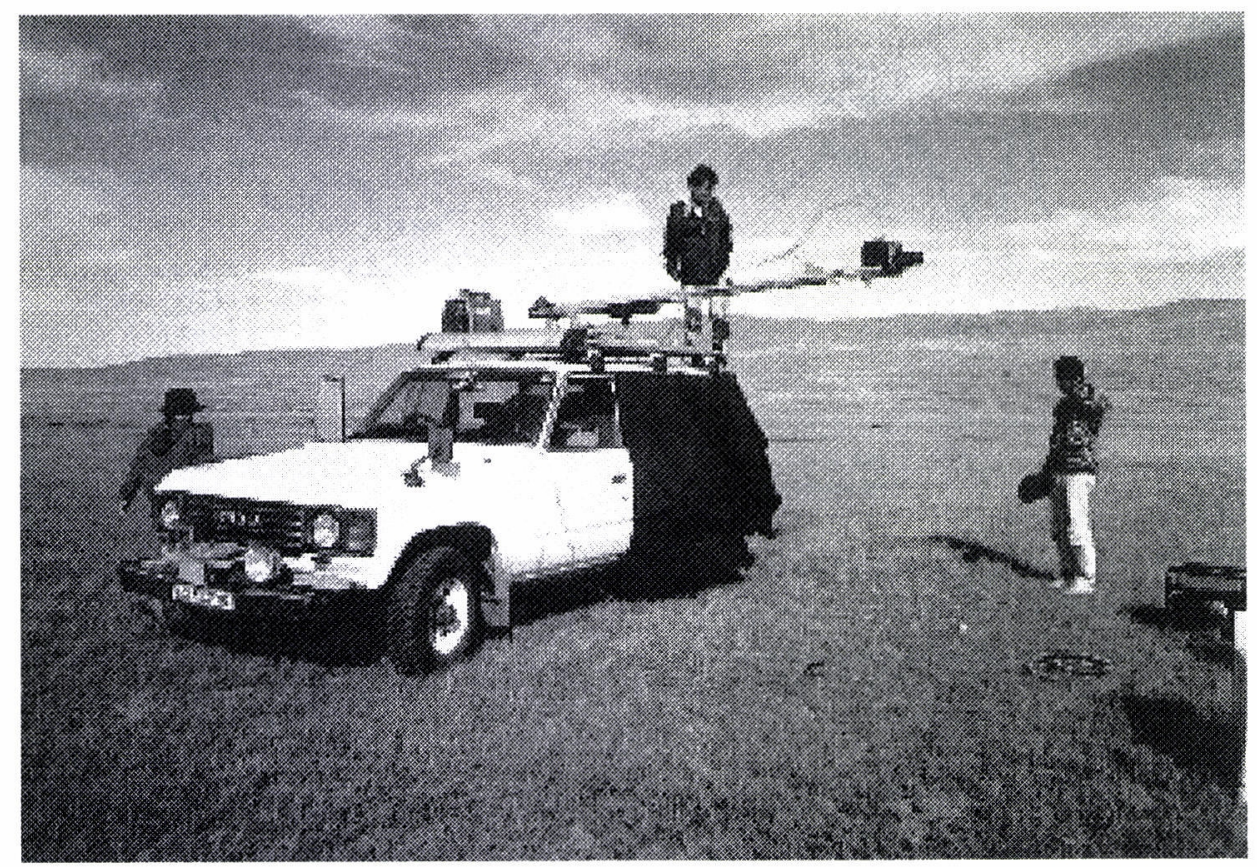

図 2 車両測定システムの外観

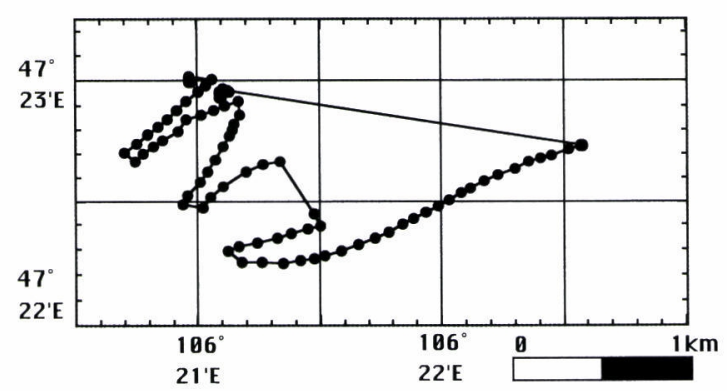

図 3 車両による観測の測定位置分布

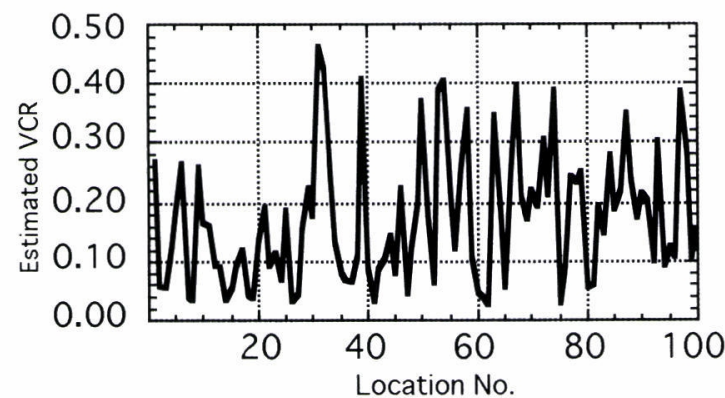

図 4 車両観測の測定地点による植生被覆率の違い
測を行った。

得られた100点分の植生被覆率をグラフ化したもの が困 4 である。なお植生被覆率は上記のシステムで取 得されるビデオ画像デー夕からもとめたものであ

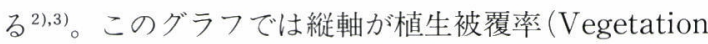
Coverage Ratio)，横軸が観測点番号であり，一見して 一様に見える草原にもバラツキがあることがわかる。

これに対して観測された植生被覆率の移動平均の平均 をとる数を 5 〜 35にして計算した結果が図 5 に示して ある。平均をとる数が約 25 個あたりを超えると，バラ ツキが少なくなることが分かる。これらの移動平均の 平均をとる数ごとに移動平均值の分散と標準偏差を計 算してグラフにしたものが闵 6 である。平均をとる数 が25個を超えてから, 標準偏差, 分散ともに小さく, ほぼ一定の值になることが分かる。つまり25点分の観 測值でバラツキがなくなるといえる。

一観測点の対象面積 S は, 分光計と CCD カメラの 視野角，観測高度から

$S=\pi \times 2.16^{2}\left[\mathrm{~m}^{2}\right] \times \tan ^{2}\left(\frac{22^{\circ}}{2}\right) \simeq 0.554\left[\mathrm{~m}^{2}\right]$

となる。先にバラツキがなくなる $5 \times 5$ 点分の観測 值でおよそ衛星の地上解像度(ここではNOAA 

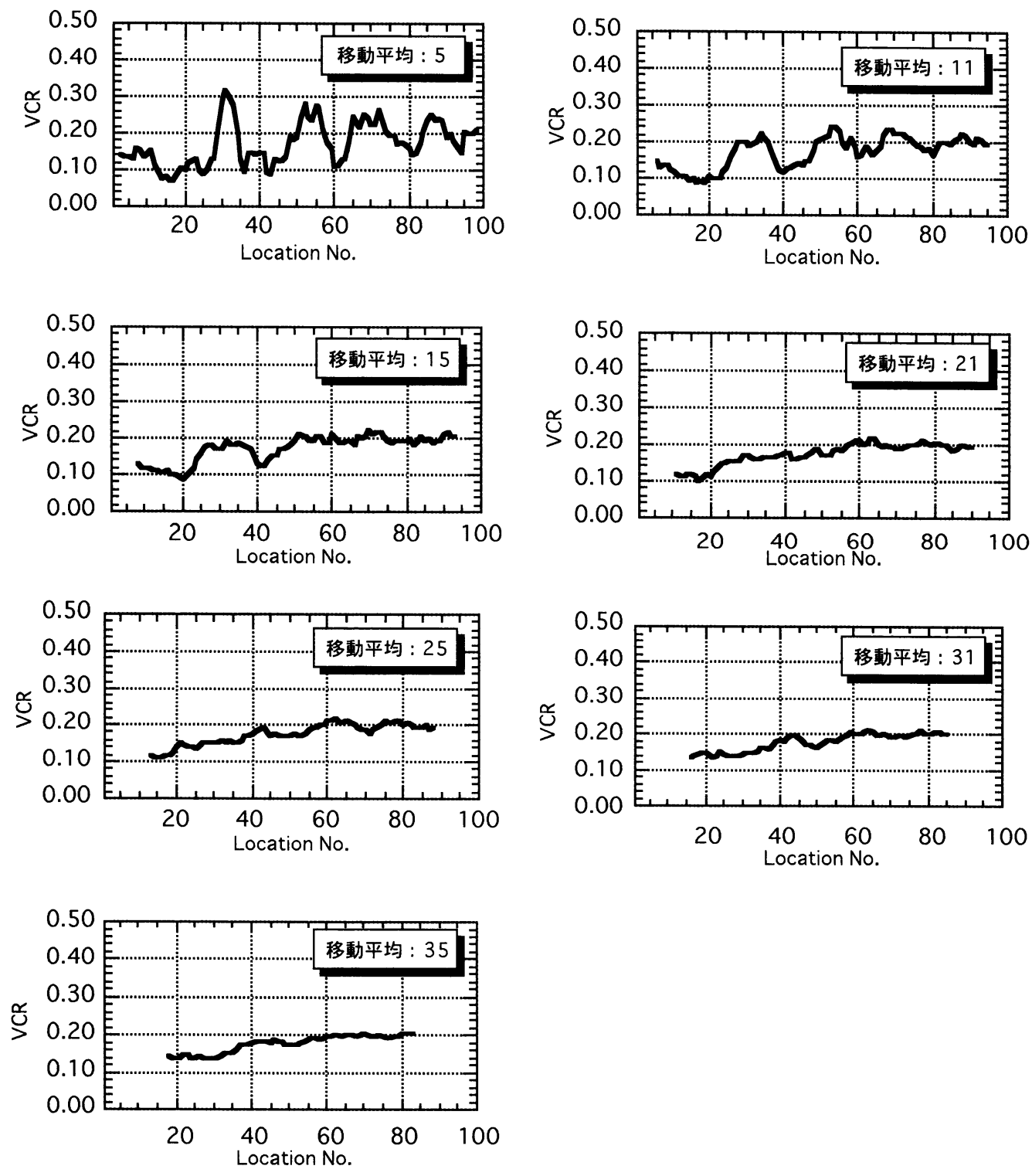

図 5 図 4 に移動平均法を施した植生被覆率の測定地点による違い

AVHRR) の観測領域（1 km× $1 \mathrm{~km})$ を代表できる と考えられるから，すなわちその面積 $S^{\prime}$ は

$S^{\prime}=0.554\left[\mathrm{~m}^{2}\right] \times 5 \times 5 \simeq 13.9\left[\mathrm{~m}^{2}\right]$

である。

\section{2 ラジコンヘリを用いた方法}

図7のよjにラジオコントロールヘリコプター（以 下ラジコンヘリ)にスペクトルメータ, GPSレシーバ, CCD カメラ, マイクロコンピュータを搭載し, 飛行す
ることにより $1 〜 150 \mathrm{~m}$ の高度から地表面を観測でき るシステムを用いてモンゴル草原を観測した4)。なお 本研究におけるラジコンヘリの観測高度は約 $55 \mathrm{~m} て ゙$ ある。

4.1で得られた結果が,たまたま同じ状態の地表面ば かりをとらえた結果であるかもしれない。そこで，ラ ジコンヘリを用いて広範囲にわたって観測を一度に行 えるシステムを利用して，広域観測領域内の任意の30 点に対して観測を行った。ラジコンヘリに装着されて 

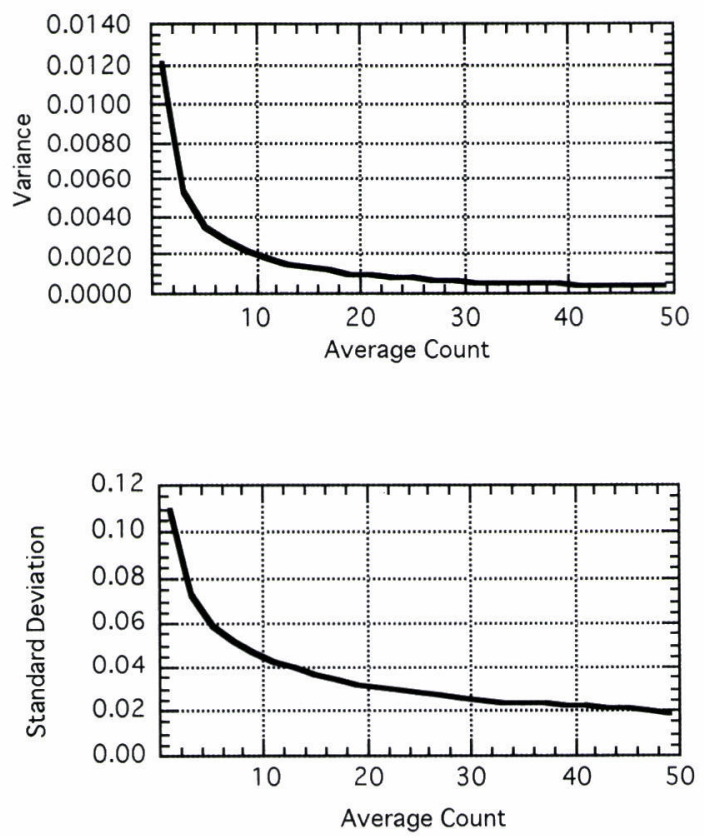

図 6 移動平均值の分散 (上図) と標準偏差 (下図)

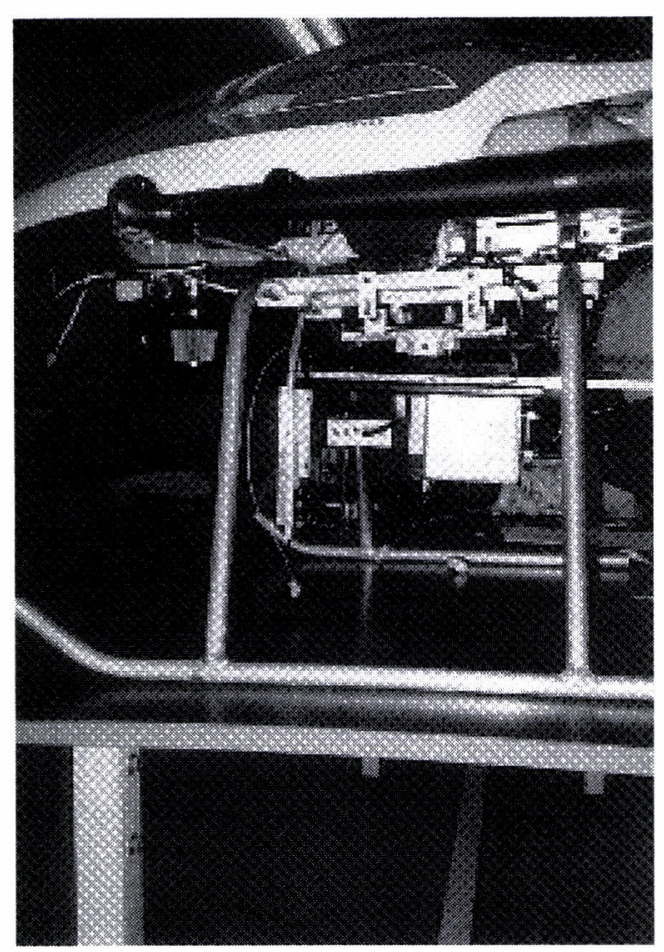

図 7 ラジコンヘリ測定システムの外観
いる分光放射計および CCD カメラがとらえる対象面 積 $S^{\prime}$ は測定条件から

$S^{\prime}=\pi \times 55^{2}\left[\mathrm{~m}^{2}\right] \times \tan ^{2}\left(\frac{22^{\circ}}{2}\right) \simeq 359\left[\mathrm{~m}^{2}\right]$

である。これによって, 約 $359 \mathrm{~m}^{2}$ を 1 ユニットとして とらえた時にバラツキが認められるかどうかの確認を 行った。

ラジコンヘリにおいても車両におけるシステム同様 CCD カメラによって地表面状態をとらえているが, ビ デオ画像の画質の問題や 1 画素内の不明瞭さから植生 被覆率を直接求めるのは困難である。そこで, まず車 両の観測によるNDVI（正規化植生指数）と植生被覆 率との関係を単回帰分析によりもとめ, ラジコンへリ で取得されている分光情報から NDVIを計算して車 両によってもとめられた植生被覆率-NDVIの関係に 代入した。車両観測によるNDVI と植生被覆率との関 係を図 8 に示す。これを参照して分かるように非常に 良い相関が見られる。ここで得られた単回帰式

$V C R=1.3537 \cdot N D V I-0.24867$

VCR：植生被覆率

にラジコンへリで取得された NDVI 值を代入し, 植 生被覆率を観測点ごとにもとめた。このラジコンへリ

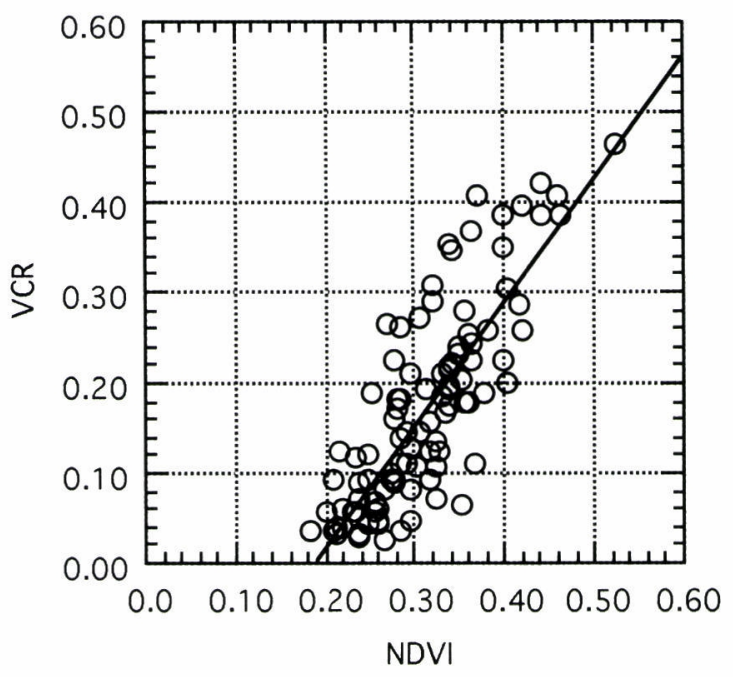

$$
\begin{aligned}
-\mathrm{VCR} & =-0.24867+1.3537 \mathrm{NDVI} \\
r & =0.81334
\end{aligned}
$$

図 8 車両観測による NDVI と植生被覆率との関係 




図 9 ヘリ観測の測定地点による植生被覆率の違い

でとらえられる植生被覆率の観測点による違いを図 9 に示す。縦軸が植生被覆率, 横軸が観測点番号である。 このグラフからわかるように観測点ごとのバラツキが ほとんどないことが分かる。この場合の分散は 0.0006 ,

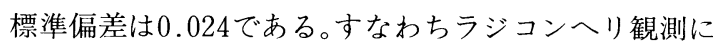
おいて, 対象面積 1 ユニット内で観測される植生被覆 率のバラツキが車両観測に比べ小さいことが確認され た。

\section{3 観測結果のまとめ}

車両を用いた方法で，ラジコンヘリ観測で取得され たデータの標準偏差 0.024 と同じバラツキのデー夕を 取得する場合, 図 6 のグラフより移動平均に必要な デー夕数は31個である。この時

$S^{\prime}=0.554 \times 31 \simeq 17.2\left[\mathrm{~m}^{2}\right]$

となる。

$359\left[\mathrm{~m}^{2}\right] \div 17.2\left[\mathrm{~m}^{2}\right] \simeq 21$

であるから，へリに装着されている分光放射計およ び CCD カメラは約21倍の対象面積をとらえているこ とになる。自然植生を対象とした場合, 21倍もの対象 面積と同等にバラツキがほとんど生じなくなる面積 $17.2 \mathrm{~m}^{2}$ を広域観測領域を代表する最小面積とするほ うが車両観測25点分を最小面積とするより安全であ る。

以上のことから広域観測領域を代表する最小面積は 約 $17.2 \mathrm{~m}^{2}$ であるといえる。すなわち, 約 $17.2 \mathrm{~m}^{2}$ の範囲 を実測することによって大面積 $(1 \mathrm{~km} \times 1 \mathrm{~km})$ の草 地相当の実測值が得られると考えられる。しかし4.2の 実験結果から，へリは車両による観測に比べて短時間 に約21倍もの視野面積を取得でき, よりバラツキの大 きな対象にも対応できることが分かった。

\section{5.まとめ}

本研究では，車両を用いた方法とラジコンヘリを用 いた方法で, 平坦で均質な草本植生が広がるモンゴル 草原において，広域観測領域 $(1 \mathrm{~km} \times 1 \mathrm{~km})$ を代表 する最小面積, 約 $17.2 \mathrm{~m}^{2}$ を求めることができた。

また，観測の効率化を進めた車両を用いた方法でも 100 点観測に約 2 時間が必要であったのに対して,ラジ コンヘリを用いた方法では 30 点観測に約 5 分で, 100 点 観測をしても15分程度である。照明条件の時間変化等 を考えるとき，このラジコンへリを用いた方法がいか に優れているかが証明されたといえる。ラジコンへリ を利用した観測の場合，観測高度を変えることによっ て，広域観測領域を代表する最小面積を短時間で推定 でき, 現地調査の効率化が四られる。また, 衛星観測 と同期した観測の場合，現地観測時の照明条件を衛星 と揃えるには光学的な観測時間のトータルをいかに短 くできるか問題になる。この点でもラジコンへリの利 用は有効である。

今後は, 本研究中で定めた方法により広域観測領域 を代表する最小面積を求めて, 対象内の草地から面積 に相当する複数のバイオマス等のサンプルを得ること が考えられる。さらに最小面積の代表性を NDVIを含 めていくつかの指標で統計学的に証明する必要があ る。しかしながらこれを証明するためには，まず誤差 を少なくするためにバイオマス等を数 $10 \mathrm{~m}^{2}$ から取得 する方法の開発が必要である。複数の数 $10 \mathrm{~m}^{2}$ の対象か らバイオマス等を経験者の練度の差異などから生じる 誤差などを気にすることなく取得できる手法はない。 この手法の開発は著者の経験から大きな困難をともな うと考えられる。

(受付日1997.4.23, 受理日1997.9.12)

\section{参考文献}

1) 山本浩万・梶原康司・本多嘉明：モンゴル平原に おける移動多点観測, 日本写真測量学会, 平成 7 年 度秋季学術講演会発表論文集，241-244，1995。

2 ) 山本浩万 - 梶原康司 - 本多嘉明：移動多点観測に よる植生被覆率推定に関する研究—モンゴル草原に おける実験一, 日本写真測量学会, 平成 8 年度年次 学術講演会発表論文集，241-244，1996。

3 ) 山本浩万：衛星による草原バイオマス計測のため 
の移動多点現地観測デー夕解析に関する研究, 日本 写真測量学会, 印刷中, 1997

4 ) Honda Y. and Kajiwara K. : Testing of Instant Aero Survey, Proceeding of the International Symposium on "The Role of Remote Sensing for The Environmental Issues in Arid and Semi-Arid Regions”, 29-32, 1997.

5 ) 本多嘉明 - 村井俊治: 世界の植生, 地学雑誌, 101 ( 6 )，514-527，1992。

6 ) 本多嘉明 - 村井俊治 - E.O. Box - 後藤真太郎 : 人 間活動による地球環境影響評価に関する研究, 東京 大学生産技術研究報告, 38( 2)，31-54，1993。

7 ) 本多嘉明：衛星デー夕を用いたモンゴル草原にお けるバイオマス計測, 第 3 回生研フォーラム「宇宙 からの地球環境モニタリング」論文集, 21-24, 1994。

8) Honda, Y : Grassland Biomass Monitoring using NOAA AVHRR, International Symposium on Remote Sensing on Remote Sensing, EMSEA, KSRS, 31-34, 1994.

9) Honda, Y. : Ground Truth Database for Global
Scale Research-Grassland Biomass Monitoring using NOAA AVHRR and Ground Truth-, Proceedings of the symposium on vegetation Monitoring, 178-186, 1995.

10) Honda, Y., Kajiwara, K., Kimura, Y.: Ground Truth Image Data for Global Scale Research, Proceedings of International Symposium on Remote Sensing, 140-143, 1995.

11) Kajiwara, K. and Kimura, Y.: Ground Truth Database for Global Scale Research International Archives of Photogrametry and Remote Sensing, Vol. XXXI, Part B7, 291-297, 1996.

12) Kajiwara, K. : Instant Aero Surveying, Proceedings of International Symposium on Remote Sensing, 121-124, 1996.

13) Kajiwara, K. and Kimura, Y.: Ground Truth Database Development, Proceedings of The Interregional Semminar on Global Mapping for Implementation of Multinational Environmental Agreements, 1996. 